\title{
Introduction to the Special Issue on Yoga Studies
}

\section{Laura M. Dunn ${ }^{1} \cdot$ Graham M. Schweig $^{2}$}

Published online: 19 May 2020

(C) Springer Nature Switzerland AG 2020

Yoga, today, is a global phenomenon. The interpretations and adaptations of yoga in a global era are increasingly related to commercialization but also, simultaneously, to broader conceptions of human well-being. Yoga, with millennia-old roots in the South Asian cultural ethos, is a leading-edge field in South Asia studies in terms of textual, anthropological, and sociological research. Emerging applications include engagement with a wide range of issues from globalization, to ecological activism, to environmental justice. This special issue on Yoga Studies includes a variety of topics, bringing together and engaging yoga's many broad applications, issues, and themes. This issue presents a diversity of subject matter and methodological approaches to illustrate yoga's global impact, as well as its ongoing importance as a path to mokṣha (liberation) to practitioners around the world.

We open our discussion with two articles that look at the textual basis for yoga metaphysics and praxis. Edwin Bryant's article, "The Metaphysical Logic of the Siddhis, Mystic Powers, in Patañjali's Yoga Sütra," explores the centrality of siddhi, or supernatural power, to the understanding of yoga metaphysics in both discourse and practice. In "'Ever New Flights' of Creativity: Improvisation in south Indian Music," William Jackson writes about yogakshema, a lesser known theory of improvisation in Indian music. The concept of yogakshema shows how creativity and tradition coalesce as an innovative and esthetic form of yoga praxis.

From the classical Sanskrit tradition, we traverse time and space to explore the impact and importance of modern and postmodern engagement and appropriation of yoga. Agi Wittich and Patrick McCartney present issues of neocolonial representation and appropriation of the image of yogi in contemporary mass media in, "The Changing Face of the Yoga Industry, Its Dharmic Roots and its Message to Women: an Analysis of Yoga Journal Magazine Covers, 1975-2019.” Patrick McCartney’s “The X+Y+Zen of "Temple Yoga" in Japan: Heretically-sealed Cultural Hybridity" examines the phenomena of hybrid forms of yoga in his ethnographic field study and analysis of temple Yoga in Japan. Thomas Cattoi's article, "Pussy Riot and Chögyam Trungpa:

Laura M. Dunn

ldunn@ses.gtu.edu

1 Graduate Theological Union, Berkeley, USA

2 Christopher Newport University, Newport News, VA, USA 
Reinventing Crazy Holiness for Post-Modernity," examines instances of crazy wisdom through an analysis of punk group, Pussy Riot, and Chögyam Trungpa - both of whom subverted social and religious norms through their post-metaphysical and post-religious representations of the Russian yurodstvo, radical ascetics living at the margins of society, and Tibetan smyon pas, crazy yogins, known for their seemingly erratic speech and irrational actions.

We conclude our thematic content with three articles on India's contribution to, relationship with, and presentation of yoga. Adheesh Sathaye investigates how practitioners of modern postural yoga are able to access and utilize premodern yoga literature and the extent to which Sanskrit language learning can enable more active participation in the process of yoga knowledge mobilization in "Sanskrit Pathways for Mobilizing Knowledge of Premodern Yoga to Studio-Based Practitioners." Christopher Miller's article "Soft-power and Bio-power: Narendra Modi's "Double Discourse" Concerning Yoga for Climate Change and Self-Care" elucidates the Indian government's two discourses on yoga-yoga as a global soft power solution and as biopower for the advancement of India's depressed economy. Christopher Chapple reflects in his article "The Academic Study of Yoga in India" on yoga as an emerging academic discipline in India, through a presentation of his studies on diploma and degree programs on Yoga Studies and Yoga Therapy in India.

Rounding out this issue are R. David Coolidge's article, "Dharma of Bhakti, Dharma of Mlecchas: Muslim Engagement with Gauḍiya Vaișnavism as a Living Tradition," which examines how The Gauḍiya Vaiṣnava tradition emerged within the context of Muslim political dominance in Bengal; Jeffrey Ruff's "Exchange and Transaction as a form of life and meaning in the logic of tantric concepts" which examines conceptual metaphors from Śaiva-Śākta traditions of Hindu tantra; and Ankur Barua's "The Agonistic Poetics of Dāsya-bhāva: The Soteriological Confrontation between Deity and Devotee," which highlight's the dialectic in the devotional songs of three medieval figures: Tulsīdās (c. 1600), Sūrdās (c. 1600), and Mādhavadeva (1489-1596), which are structured primarily by the devotional attitude of a servant $(d \bar{a} s a)$ towards the Lord. The line up of original articles concludes with J. Shashi Kiran Reddy's, "Vajranrtyam: A Phenomenological Look at the Cham or Lama Dance as a Meditative Experience."

We conclude with two book reviews by Jeff Long and Christopher Miller on Parveen Jain's new book, Introduction to Jain Philosophy, and a review discussion on Nishikant Kolge's book, Gandhi Against Caste, which is spread across two articles_-Samiksha Goyal's "Gandhi: Philosopher or Pragmatic Politician?" and Nishikant Kolge's "Gandhi: The Mixture Was the Essence."

The articles in this special issue on Yoga Studies map yoga through text, praxis, politics, and esthetics in a variety of textual, historical, and cultural milieus, illustrating yoga's global impact. Despite our best attempts representing yoga's broad applications and theories, the articles in this issue only scratch the surface of a millennia-old tradition that continues to shape and be shaped by various religious, social, and ethical influences around the world. 